\title{
KESEJAHTERAAN KELUARGA PESERTA DAN BUKAN PESERTA PROGRAM GERAKAN PEREMPUAN UNTUK OPTIMALISASI PEKARANGAN (GPOP)
}

\author{
Riza $^{\left.1,2^{*}\right)}$, Hartoyo ${ }^{3}$, Istiqlaliyah Muflikhati ${ }^{3}$ \\ ${ }^{1}$ Direktorat Jenderal Holtikultura, Kementerian Pertanian, Jakarta 12550, Indonesia \\ ${ }^{2}$ Program Studi Ilmu Keluarga dan Perkembangan Anak, Sekolah Pascasarjana, Institut Pertanian Bogor, \\ Bogor 16680, Indonesia \\ ${ }^{3}$ Departemen Ilmu Keluarga dan Konsumen, Fakultas Ekologi Manusia, Institut Pertanian Bogor, \\ Bogor 16680, Indonesia \\ *E-mail: riza_mufidah@yahoo.co.id
}

\begin{abstract}
Abstrak
Program Gerakan Perempuan untuk Optimalisasi Pekarangan (GPOP) adalah salah satu upaya pemerintah melalui Kementrian Pertanian yang dilaksanakan sejak tahun 2011 untuk mendorong keluarga mengelola pekarangannya secara optimal dalam rangka peningkatan kesejahteraan keluarga. Tujuan dari penelitian ini adalah untuk menganalisis kesejahteraan keluarga pada keluarga peserta dan bukan peserta GPOP dan faktorfaktor yang memengaruhinya. Penelitian ini melibatkan 60 keluarga peserta GPOP dan 60 keluarga bukan peserta GPOP yang dipilih secara acak. Kesejahteraan keluarga diukur dengan menggunakan indikator kesejahteraan objektif berdasarkan garis kemiskinan menurut BPS dan indikator kesejahteraan subjektif berdasarkan penilaian istri terhadap berbagai aspek kesejahteraan keluarganya. Penelitian ini menemukan bahwa justru keluarga yang tidak menjadi peserta GPOP lebih tinggi ketercapaian dalam memanfaatkan pekarangan dibandingkan peserta. Hasil penelitian menunjukkan bahwa sebagian besar keluarga baik peserta GPOP ataupun bukan telah sejahtera menurut pengukuran kedua kriteria, baik objektif maupun subjektif. Namun capaian kesejahteraan keluarga peserta GPOP lebih tinggi dibanding keluarga bukan peserta. Analisis regresi menunjukkan bahwa kesejahteraan keluarga dipengaruhi oleh jumlah aset keluarga, dan status keanggotaan GPOP tidak memengaruhi.
\end{abstract}

Kata kunci: kesejahteraan keluarga, kesejahteraan objektif, kesejahteraan subjektif, pemanfaatan pekarangan

\section{Family's Well-being of Participants and Nonparticipants of Women's Movement for Homegarden Optimization Program (GPOP)}

\begin{abstract}
Program of Women's Movement for Home garden Optimization (GPOP) was one of the government's efforts to encourage families to manage home garden optimally in order to improve the family well-being. This program was conducted since 2011 by Ministry of Agriculture. The aim of this research was to analyze the well-being of GPOP participant's family and nonparticipant's family in Depok City, West Java Province; and to analyze the factors that influenced the well-being. This research involved 60 GPOP participants' family and 60 nonparticipant's family that chosen by random sampling. Family well-being measured by using objective indicator based on poverty line according to BPS and subjective indicator based on assessment of wive on various aspects of her family well-being. This study found that even families who did not become participants of GPOP had higher achievement of optimization of the home garden than participants. The results showed that most familyies, both participants and nonparticipants, had been prosperous according to the measurement of two indicator, objective and subjectife assessment. However, the level of the family well-being of participants was higher than nonparticipants. Moreover, family's well-being was affected by the amount of family assets, but it was not influenced by membership of GPOP.
\end{abstract}

Keywords: family well-being, homegarden optimization, objective well-being, subjective well-being

\section{PENDAHULUAN}

Tujuan dari setiap keluarga adalah tercapainya kesejahteraan yang dapat dirasakan semua anggota keluarga. Seperti yang tertera dalam Pasal 4 UU No. 52 Tahun 2009 tentang Perkembangan Kependudukan dan Pembangunan Keluarga, bahwa pembangunan keluarga bertujuan untuk meningkatkan kualitas keluarga agar dapat timbul rasa aman, tenteram, dan harapan masa depan yang lebih baik dalam mewujudkan kesejahteraan lahir dan kebahagiaan batin. 
Menurut Behnke dan MacDermid (2004), kesejahteraan merupakan kualitas hidup seseorang atau unit sosial lainnya. Indikator umum kesejahteraan keluarga menurut Weston, Gray dan Stanton (2004) diantaranya keadaan keuangan dan material keluarga, pekerjaan orang tua, kepuasan anggota keluarga terhadap hubungan antar anggota keluarga, dan gaya pengasuhan orang tua serta kualitas fungsi keluarga. Milligan et al., (2006) menjelaskan beberapa komponen yang berkontribusi terhadap kesejahteraan keluarga yaitu pendapatan, pendidikan, kesehatan, kualitas hubungan antar anggota keluarga dan fungsi keluarga. Rambe (2004) menyebutkan bahwa kesejahteraan keluarga ditentukan oleh empat faktor yaitu pendidikan, kondisi tempat tinggal, harga dan pengeluaran.

Kesejahteraan keluarga dapat dicapai jika semua sumber daya keluarga dapat dikelola dengan baik. Menurut Firebaugh (1991), keluarga merupakan balok-balok dalam proses pembangunan sosial dan ekonomi. Manusia, dalam hal ini keluarga dan lingkungan terdekatnya atau yang disebut sebagai microenvironment merupakan satu kesatuan yang terintegrasi dan saling mempengaruhi secara menguntungkan antara satu dengan yang lainnya (Bubolz \& Sontag, 1988).

Pekarangan rumah merupakan salah satu sumber daya lingkungan fisik keluarga yang merupakan praktek kuno yang tersebar luas di seluruh dunia. Pekarangan dapat dikelompokkan sebagai campuran dari dapur, halaman belakang, peternakan, atau homestead garden (Terra, 1958; Puri \& Nair, 2004; Rowe, 2009). Secara umum, pekarangan merupakan tempat berbudidaya pada lahan sempit di sekitar rumah (Odebodo, 2006). Struktur, fungsi, dan kontribusi pekarangan bervariasi dalam wilayah geografis. Pekarangan memenuhi kebutuhan sosial, budaya dan ekonomi serta memberikan sejumlah layanan ekosistem. Manfaat pekarangan itu tidak berdiri sendiri, tapi saling tergantung dan mendukung antar berbagai unsur manfaat yang menghasilkan manfaat yang lebih besar lagi (Galhena, Freed, \& Maredia, 2013).

Mitchell dan Hanstad (2004) menegaskan bahwa pekarangan berkontribusi pada kesejahteraan ekonomi keluarga dalam berbagai cara. Hasil pekarangan dapat dijual untuk mendapatkan tambahan penghasilan (Niñez 1985; Torquebiau, 1992). Hasil penelitian di Nepal, Cambodia, dan Papua New Guinea menunjukkan bahwa pendapatan yang dihasilkan dari penjualan buah, sayur dan ternak dari pekarangan memungkinkan keluarga untuk membeli makanan tambahan, menabung dan membiayai pendidikan anak-anak (Vasey, 1985; lannotti, Cunningham, Ruel, 2009). Keluarga di Vietnam mampu menghasilkan lebih dari 22 persen pendapatan mereka dari kegiatan di pekarangan tergantung pada waktu yang dicurahkan, tenaga kerja yang terlibat dalam pengelolaan pekarangan dan luas pekarangan (Trinh et al., 2003). Pekarangan dapat menghasilkan makanan untuk konsumsi keluarga dan penyangga ekonomi keluarga pada saat terjadi fluktuasi harga (Torres, 1988; Wickramasingle, 1995).

Banyaknya manfaat pekarangan menyebabkan munculnya berbagai upaya pemanfaatan pekarangan, baik itu dari pemerintah maupun swasta. Pada tahun 2011, Direktorat Jenderal Hortikultura, Kementerian Pertanian RI mencanangkan Program Gerakan Perempuan untuk Optimalisasi Pekarangan (GPOP). Kegiatan yang dilakukan adalah menstimulasi keluarga yang tergabung dalam kelompok, untuk memanfaatkan pekarangan dengan memberikan bibit tanaman cabai, sarana prasarana pendukung budidaya, dan pelatihan teknis budidaya, dan tanaman cabai. Kota Depok merupakan satu dari 18 kota di Indonesia yang mendapatkan program GPOP dari Direktorat Jenderal Hortikultura. Keluarga yang dapat mengakses program GPOP ini harusnya dapat memanfaatkan bantuan dengan mengelola pekarangan secara optimal. Selain itu, dengan pengelolaan sumber daya keluarga lainnya, yang dilakukan secara efektif dan efisien, diharapkan dapat mencapai kesejahteraan keluarga.

Berdasarkan pemaparan tersebut, penelitian ini bertujuan untuk menganalisis kesejahteraan keluarga peserta dan bukan peserta GPOP dan menganalisis faktor-faktor yang memengaruhi tingkat kesejahteraan keluarga.

\section{METODE}

Desain penelitian menggunakan cross sectional. Penelitian ini merupakan penelitian survei yang dilakukan pada bulan Agustus sampai dengan bulan Oktober 2012 di Kota Depok. Pemilihan lokasi penelitian dilakukan secara purposive dengan pertimbangan bahwa Kota Depok merupakan merupakan salah satu daerah yang mendapatkan program Gerakan Perempuan untuk Optimalisasi Pekarangan (GPOP). 
Populasi dalam penelitian ini adalah keluarga yang tinggal di Kota Depok, baik yang menjadi peserta maupun bukan peserta program GPOP. Contoh dalam penelitian ini adalah keluarga peserta dan bukan peserta GPOP. Contoh dipilih secara acak dari dua kecamatan terpilih. Pemilihan dua kecamatan dilakukan secara acak dari sebelas kecamatan di Kota Depok, yaitu Kecamatan Cipayung dan Cimanggis. Kemudian dari setiap kecamatan dipilih secara purposive kelurahan yang memiliki kelompok GPOP, yaitu Kelurahan Tugu di Kecamatan Cimanggis dan Kelurahan Cipayung Jaya di Kecamatan Cipayung. Pada satu kelurahan terpilih terdapat satu kelompok peserta Program GPOP yang memiliki anggota 175 keluarga, dan kemudian dipilih 30 orang secara acak di kelompok tersebut. Contoh bukan peserta program dipilih secara acak sebanyak 30 keluarga dari keluarga yang bukan peserta yang berada di kelurahan yang sama. Jumlah total contoh yang terpilih adalah sebanyak 120 keluarga, yang terbagi menjadi 60 keluarga peserta dan 60 keluarga bukan peserta.

Data primer dalam penelitian ini meliputi karakteristik keluarga, optimalisasi pemanfaatan pekarangan dan tingkat kesejahteraan keluarga. Pengumpulan data primer dilakukan dengan cara wawancara terstruktur dengan alat bantu kuesioner dan observasi langsung kondisi lingkungan tempat tinggal dan pekarangan keluarga. Karakteristik keluarga terdiri atas usia suami dan istri, pendidikan suami dan istri, pekerjaan suami dan istri, pendapatan keluarga per kapita, pengeluaran keluarga per kapita, besar keluarga, tempat tinggal dan aset. Optimalisasi pemanfaatan pekarangan diperoleh sebagai hasil pengukuran dari tiga indikator yaitu tingkat pemanfaatan pekarangan, komoditas yang dihasilkan pekarangan dan manfaat hasil pekarangan. Tingkat kesejahteraan diukur berdasarkan garis kemiskinan BPS dan penilaian istri terhadap berbagai aspek kesejahteraan keluarga.

Usia suami dan istri dikategorikan berdasarkan Hurlock (1990) menjadi dewasa awal (18-40 tahun), dewasa pertengahan (41-60 tahun) dan dewasa lanjut ( $>60$ tahun). Pendidikan suami dan istri diukur berdasarkan lama pendidikan formal yang ditempuh yang selanjutnya dikategorikan menjadi tiga kategori menurut Sistem Pendidikan Nasional, yaitu pendidikan dasar (1-9 tahun), pendidikan menengah (10-12 tahun) dan pendidikan tinggi (>12 tahun). Pekerjaan suami dibedakan menjadi tidak bekerja, PNS/Polisi/TNI, karyawan swasta dan wiraswasta, sementara pekerjaan istri dikategorikan menjadi tidak bekerja dan bekerja. Pendapatan dan pengeluaran keluarga per kapita dikategorikan dalam empat ketegori berdasarkan Garis Kemiskinan Kota Depok yaitu kurang dari Rp310.279,00, antara Rp310.280,00 dan Rp620.558,00, antara Rp620.559,00 dan Rp930.827,00 dan lebih dari Rp 930.837,00. Besar keluarga diukur berdasarkan jumlah seluruh anggota keluarga dan dikategorikan berdasarkan BKKBN (1996) menjadi tiga ketegori yaitu keluarga kecil ( $\leq 4$ orang), keluarga sedang (5-7 orang) dan keluarga besar ( $\geq 8$ orang). Tempat tinggal dibedakan menjadi kompleks dan bukan kompleks. Aset diukur berdasarkan jumlah jenis aset yang dimiliki keluarga, dengan maksimal jumlah adalah sebanyak 28 jenis aset.

Optimalisasi pemanfaatan pekarangan diperoleh sebagai hasil pengukuran dari tiga indikator yaitu: (a) Tingkat pemanfaatan pekarangan didapat dari hasil persentase luas pekarangan yang dimanfaatkan keluarga untuk ditanami tanaman, atau memelihara ikan/ternak $\left(\mathrm{m}^{2}\right)$ dengan luas lahan pekarangan yang dimiliki keluarga $\left(\mathrm{m}^{2}\right)$, (b) komoditas yang dihasilkan pekarangan dan (c) manfaat hasil pekarangan. Oleh karena ketiga ukuran tersebut tidak sama, maka masingmasing skor ditransformasikan ke dalam bentuk indeks. Dengan demikian dihasilkan tiga indeks, yang selanjutnya indeks optimalisasi pemanfaatan pekarangan diperoleh dari rata-rata indeks tingkat pemanfaatan pekarangan, indeks komoditas yang dihasilkan dan indeks manfaat hasil pekarangan.

Tingkat kesejahteraan keluarga diukur menggunakan dua indikator yaitu indikator garis kemiskinan BPS dan penilaian istri terhadap aspek kesejahteraan keluarga. Kesejahteraan menurut BPS diukur menggunakan indikator garis kemiskinan Kota Depok yaitu Rp310.279,00 per kapita per bulan. Berdasarkan indikator ini, keluarga dikategorikan menjadi dua kategori yaitu keluarga miskin dengan pengeluaran per kapita per bulan lebih kecil atau sama dengan Rp310.279,00 per kapita per bulan, sedangkan keluarga dengan pengeluaran besar dari Rp310.279,00 per kapita per bulan maka keluarga tersebut dikategorikan sebagai keluarga tidak miskin. Kesejahteraan menurut penilaian istri diukur menggunakan instrumen yang mengacu pada penelitian yang dilakukan Rambe (2004), yang terdiri atas 45 pertanyaan dengan dua pilihan jawaban yaitu ya (skor 1 ) dan tidak (skor 0). Instrumen yang digunakan telah reliabel dengan nilai Cronbach's alpha sebesar 0,803 . Skor yang diperoleh keluarga dijumlahkan dan dihitung persentasenya. 
Selanjutnya berdasarkan persentase skor, keluarga dikategorikan menjadi keluarga sejahtera (persentase skor $\geq 75$ ) dan keluarga tidak sejahtera (persentase skor < 75). Pengukuran kedua indikator ini selanjutnya menghasilkan keluarga yang sejahtera menurut hasil pengukuran BPS dan penilaian istri terhadap kesejahteraan keluarganya, serta tidak sejahtera menurut hasil pengukuran kedua indikator ini.

Data yang telah dikumpulkan dalam penelitian ini dianalisis menggunakan analisis deskriptif dan statistik inferensia. Analisis deskriptif digunakan untuk menghitung nilai minimum, nilai maksimum, nilai rata-rata, serta standar deviasi. Analisis statistik inferensia yang digunakan adalah uji beda t, uji khi kuadrat, dan uji regresi logistik. Uji beda t digunakan untuk menguji perbedaan antara kelompok peserta dan bukan peserta program GPOP. Sementara itu, uji regresi logistik digunakan untuk menganalisis variabel yang berpengaruh terhadap tingkat kesejahteraan keluarga, yang mana dalam pengujian ini hanya mengikutsertakan keluarga yang sejahtera dan tidak sejahtera menurut hasil kedua pengukuran dengan jumlah 77 keluarga.

\section{HASIL}

\section{Karakteristik Keluarga}

Berdasarkan hasil penelitian karakteristik keluarga, rentang usia suami berada pada rentang 30-69 tahun dengan usia rata-rata 47,36 tahun, sedangkan istri dalam penelitian ini adalah 27-63 tahun dengan usia rata-rata sebesar 43,59 tahun. Usia suami dan istri yang terlibat dalam penelitian ini tergolong usia produktif. Berdasarkan rata-rata usia, suami (47,1 tahun) dan istri (42,90 tahun) pada kelompok bukan peserta program GPOP lebih muda dibandingkan suami (47,65 tahun) dan istri (44,28 tahun) pada kelompok peserta GPOP.

Lama pendidikan suami berada pada rentang 4-18 tahun, sedangkan lama pendidikan istri berada pada rentang 6-18 tahun (Tabel 1). Berdasarkan lama pendidikan, suami dan istri dari kelompok bukan peserta program menempuh pendidikan yang lebih lama dibandingkan dengan kelompok peserta program. Hasil penelitian menunjukkan bahwa sebagian besar istri dalam penelitian ini tidak bekerja $(72,5 \%)$ dan sebagian besar suami bekerja $(92,5 \%)$. Keluarga yang terlibat dalam penelitian ini memiliki jumlah anggota keluarga 17 orang dengan rata-rata sebanyak 4,01 orang.

Rata-rata pendapatan keluarga per kapita per bulan berkisar antara Rp83.333,00 Rp2.500.000,00. Jika dibandingkan antara kedua kelompok terlihat bahwa rata-rata pendapatan per kapita per bulan keluarga bukan peserta program lebih besar daripada keluarga peserta program. Hasil uji beda t menunjukkan terdapat perbedaan pendapatan yang signifikan antara keluarga peserta dan bukan peserta GPOP $(p<0,05)$. Pengeluaran keluarga per kapita per bulan berkisar antara Rp150.000,00-Rp1.687.500,00.

Keluarga bukan peserta GPOP memiliki rata-rata pengeluaran yang lebih besar dibandingkan dengan keluarga peserta. Keluarga pada penelitian ini bertempat tinggal di komplek dan bukan komplek (perkampungan). Sebagian besar keluarga bertempat tinggal di perkampungan $(66,7 \%)$. Aset yang dimiliki keluarga terdiri atas tempat tinggal, kendaraan, peralatan elektronik, perlengkapan rumah tangga, benda berharga, dan perabot rumah tangga. Jumlah aset yang dimiliki keluarga berkisar antara 8 sampai 28 jenis dengan rata-rata jumlah aset yang dimiliki adalah 17,27 jenis.

Tabel 1 Nilai rata-rata, standar deviasi, dan koefisien uji beda untuk karakteristik keluarga peserta dan bukan peserta program GPOP

\begin{tabular}{lcccc}
\hline Karakteristik & Peserta & Bukan Peserta & Total & $p$-value \\
\hline Usia Istri (tahun) & $44,3 \pm 6,8$ & $42,9 \pm 7,6$ & $43,6 \pm 7,2$ & 0,296 \\
Usia Suami (tahun) & $47,6 \pm 6,2$ & $47,1 \pm 7,7$ & $47,4 \pm 6,9$ & 0,156 \\
Pendidikan Istri (tahun) & $10,5 \pm 2,7$ & $11,5 \pm 2,9$ & $10,9 \pm 2,8$ & 0,061 \\
Pendidikan Suami & $11,5 \pm 2,6$ & $12,0 \pm 3,4$ & $11,7 \pm 3,0$ & 0,187 \\
(tahun) & & & \\
Besar keluarga (orang) & $3,9 \pm 1,2$ & $4,1 \pm 0,9$ & $4,0 \pm 1,1$ & 0,465 \\
Pendapatan per kapita & $750.704,4 \pm$ & $925.001,3 \pm$ & $837.852,8 \pm$ & $0,038^{\star}$ \\
(Rp/bulan) & $409.774,9$ & $496.739,5$ & $461.789,1$ & \\
Pengeluaran per kapita & $441.999,4 \pm$ & $526.707,2 \pm$ & $484.353,27$ & 0,076 \\
(Rp/bulan) & $250.852,9$ & $267.312,9$ & $\pm 261.602,7$ & \\
Aset (jumlah jenis) & $16,7 \pm 4,1$ & $17,8 \pm 4,4$ & $17,3 \pm 4,2$ & 0,157 \\
\hline Keterangan: * Signifikan pada $p \leq 0,05$ & & &
\end{tabular}




\section{Pemanfaatan Pekarangan}

Pemanfaatan pekarangan diukur dengan menggunakan tiga indikator yaitu tingkat pemanfaatan pekarangan, komoditas yang dihasilkan pekarangan, dan manfaat hasil pekarangan. Tingkat pemanfaatan pekarangan diukur berdasarkan persentase perbandingan antara luas pekarangan yang dimanfaatkan untuk berkebun/beternak dengan luas pekarang-an yang dimiliki keluarga. Luas pekarangan keluarga secara keseluruhan berkisar antara $2 \mathrm{~m}^{2}$ sampai $540 \mathrm{~m}^{2}$. Pekarangan keluarga bukan peserta GPOP lebih luas dibandingkan dengan pekarangan peserta GPOP. Hasil penelitian menunjukkan bahwa tingkat pemanfaatan pekarangan keluarga bukan peserta GPOP lebih tinggi dibandingkan dengan keluarga peserta GPOP (Tabel 2). Rata-rata luas pekarangan keluarga peserta dan bukan peserta berbeda signifikan $(p<0,01)$. Pekarangan yang dimiliki keluarga dimanfaatkan untuk berbagai keperluan anggota keluarga, diantaranya untuk bercocok tanam dan memelihara ternak/ikan.

Komoditas yang paling banyak ditanam di pekarangan adalah tanaman hias atau florikultura (Tabel 3). Selain itu, komoditas lain yang ditanam di pekarangan adalah tanaman obat, buah, bumbu dapur, dan sayur. Komoditas sayuran paling sedikit ditanam di pekarangan oleh keluarga pada kedua kelompok. Hal ini disebabkan karena pemeliharaan tanaman sayuran tidak semudah tanaman lainnya. Jika dibandingkan antar kedua kelompok keluarga, ternyata keluarga peserta lebih banyak menanam sayuran, buah dan tanaman obat dibanding keluarga bukan peserta. Sebaliknya untuk beternak dan memelihara ikan lebih banyak dilakukan oleh keluarga bukan peserta. Hal ini bisa disebabkan karena pekarangan keluarga bukan peserta lebih luas, yang memungkinkan mereka untuk beternak dan/atau memelihara ikan.

Tabel 2 Rata-rata dan standar deviasi pemanfaatan pekarangan

\begin{tabular}{lcccc}
\hline $\begin{array}{l}\text { Pemanfaatan } \\
\text { Pekarangan }\end{array}$ & Peserta & $\begin{array}{c}\text { Bukan } \\
\text { Peserta }\end{array}$ & Total & p-value \\
\hline Luas & $32,9 \pm$ & $72,4 \pm$ & $52,6 \pm$ & $0,007^{* *}$ \\
$\begin{array}{l}\text { pekarangan } \\
\left(\mathrm{m}^{2}\right)\end{array}$ & 42,9 & 102,2 & 80,5 & \\
$\begin{array}{l}\text { Luas } \\
\text { pemanfaatan }\end{array}$ & $5,3 \pm 14$, & $10,8 \pm$ & $8,1 \pm 1$ & 0,096 \\
pekarangan & 2 & 21,5 & 8,3 & \\
$\left(\mathrm{~m}^{2}\right)$ & & & & \\
$\begin{array}{l}\text { Tingkat } \\
\text { pemanfaatan }\end{array}$ & $17,4 \pm$ & $23,0 \pm$ & $20,2 \pm$ & 0,162 \\
$\begin{array}{l}\text { Pekarangan } \\
(\%)\end{array}$ & 18,2 & 25,0 & 21,9 & \\
\hline Keterangan: * ${ }^{*}$ Signifikan pada $p \leq 0,01$ & & & \\
\end{tabular}

Sebaran persentase keluarga peserta dan bukan peserta program GPOP berdasarkan pemanfaatan hasil pekarangan disajikan pada Tabel 3. Sebagian besar hasil yang diperoleh dari pemanfaatan pekarangan $(58,3 \%)$ dikonsumsi sendiri oleh keluarga. Selain dikonsumsi, hasil pekarangan ini juga ada yang dijual (14,2\%). Keluarga bukan peserta program GPOP lebih cenderung memanfaatkan pekarangan secara ekonomis. Hasil pemanfaatan pekarangan yang diperoleh dijual. Hasil pekarangan yang dijual oleh keluarga bukan peserta program GPOP lebih besar $(20,0 \%)$ dibandingkan dengan keluarga peserta program GPOP. Sementara itu, peserta program GPOP lebih cenderung memanfaatkan pekarangan secara sosial. Hasil yang diperoleh dari pemanfaatan pekarangan dibagikan ke tetangga. Jumlah hasil pekarangan yang dibagikan oleh keluarga peserta program GPOP ke tetangga lebih besar (61,7\%) dibandingkan dengan keluarga bukan peserta program GPOP.

Keluarga dengan pekarangan sempit masih bisa memanfaatkan pekarangannya secara optimal dengan melakukan teknik budi daya tanaman vertikultur, yaitu menanam tanaman secara vertikal atau bertingkat dengan menggunakan pot. Penanaman dengan cara vertikultur sudah mulai dilakukan keluarga walaupun masih sedikit (20,8\%). Keluarga peserta program GPOP lebih banyak $(26,7 \%)$ yang menggunakan vertikultur ini dibanding keluarga bukan peserta program GPOP $(15,0 \%)$.

Tabel 3 Sebaran persentase keluarga peserta dan bukan peserta program GPOP berdasarkan pemanfaatan pekarangan

\begin{tabular}{lccc}
\hline $\begin{array}{l}\text { Pemanfaatan } \\
\text { pekarangan }\end{array}$ & $\begin{array}{c}\text { Peserta } \\
\text { GPOP }\end{array}$ & $\begin{array}{c}\text { Bukan } \\
\text { peserta } \\
\text { GPOP }\end{array}$ & Total \\
\hline
\end{tabular}

\begin{tabular}{|c|c|c|c|}
\hline \multicolumn{4}{|c|}{ A. Komoditas yang dihasilkan } \\
\hline 1. Sayuran & 36,7 & 20,0 & 28,3 \\
\hline 2. Buah & 73,3 & 55,0 & 64,2 \\
\hline $\begin{array}{l}\text { 3. Tanaman } \\
\text { obat }\end{array}$ & 81,7 & 55,0 & 68,3 \\
\hline $\begin{array}{l}\text { 4. Bumbu } \\
\text { dapur }\end{array}$ & 51,7 & 53,3 & 52,5 \\
\hline $\begin{array}{l}\text { 5. Tanaman } \\
\text { hias }\end{array}$ & 83,3 & 83,3 & 83,3 \\
\hline 6. Ternak & 16,7 & 20,0 & 18,3 \\
\hline 7. Ikan & 8,3 & 18,3 & 13,3 \\
\hline \multicolumn{4}{|c|}{ B. Manfaat hasil pekarangan } \\
\hline 1. Dikonsumsi & 65,0 & 51,7 & 58,3 \\
\hline 2. Dijual & 8,3 & 20,0 & 14,2 \\
\hline $\begin{array}{l}\text { 3. Diberikan } \\
\text { pada } \\
\text { tetangga }\end{array}$ & 61,7 & 46,7 & 54,2 \\
\hline
\end{tabular}


Tabel 4 Kategori optimalisasi pemanfaatan pekarangan

\begin{tabular}{lrrr}
\hline Kategori & Peserta & $\begin{array}{c}\text { Bukan } \\
\text { Peserta }\end{array}$ & \multicolumn{1}{c}{ Total } \\
\hline Kurang & 31,7 & 40,0 & 35,8 \\
Sedang & 61,7 & 48,3 & 55,0 \\
Tinggi & 6,7 & 11,7 & 9,2 \\
\hline Total & 100,0 & 100,0 & 100,0 \\
Minimum- & $13,3-80,0$ & $0,0-86,6$ & $0,0-86,7$ \\
Maksimum & & & \\
Rata-rata & $44,8 \pm 16,8$ & $41,4 \pm 20,7$ & $43,1 \pm 18,9$ \\
standar & & & \\
deviasi & & & \\
\hline
\end{tabular}

Rata-rata indeks pemanfaatan pekarangan keluarga peserta sebesar 44,8, sedangkan keluarga bukan peserta sebesar 41,4 . Hasil uji t tidak menunjukkan perbedaan yang signifikan $(p>0,05) \quad$ (Tabel 4). Pemanfaatan pekarangan sebagian besar keluarga berada pada kategori sedang $(55,0 \%)$. Pada optimalisasi pemanfaatan pekarangan yang berada pada kategori kurang, keluarga bukan peserta lebih besar $(40,0 \%)$ jumlahnya dibanding keluarga peserta $(31,7 \%)$, dan keluarga bukan peserta memiliki nilai minimum indeks optimalisasi pemanfaatan pekarangan yang sangat rendah dibandingkan dengan keluarga peserta. Ini menunjukkan bahwa terdapat keluarga bukan peserta yang tidak memanfaatkan pekarangan sama sekali untuk bercocok tanam ataupun memelihara ternak/ikan.

\section{Tingkat Kesejahteraan Keluarga}

Sebagian besar keluarga sejahtera menurut kriteria BPS $(71,7 \%)$ dan kriteria penilaian istri $(69,2 \%)$. Keluarga yang sejahtera menurut pengukuran BPS, 26,7 persen diantaranya tidak sejahtera menurut kriteria penilaian istri. Sebaliknya, sebanyak 58,8 persen keluarga yang tidak sejahtera menurut kriteria BPS namun sejahtera menurut kriteria penilaian istri. Tabel 5 menunjukkan sebagian besar keluarga $(73,3 \%)$ sejahtera menurut pengukuran kedua kriteria yaitu kriteria BPS dan kriteria penilaian istri. Sedangkan keluarga yang tidak sejahtera menurut kedua kriteria adalah sebanyak 41,2 persen.

Hasil uji khi kuadrat tidak menunjukkan adanya perbedaan yang signifikan antara tingkat kesejahteraan menurut kriteria penilaian istri dengan kriteria BPS $(p>0,05)$. Keluarga yang sejahtera menurut kedua kriteria dan tidak sejahtera menurut kedua kriteria berjumlah 77 keluarga atau sebanyak 64,2 persen dari jumlah contoh. Jika dibandingkan kedua keluarga terlihat keluarga peserta lebih banyak yang sejahtera menurut pengukuran kedua kriteria (82,9\%) dibandingkan dengan keluarga bukan peserta $(64,4 \%)$.
Tabel 5 Sebaran keluarga berdasarkan tingkat kesejahteraan keluarga menurut kriteria BPS dan penilaian istri

\begin{tabular}{lrrr}
\hline $\begin{array}{l}\text { Tingkat } \\
\text { kesejahteraan } \\
\text { menurut kriteria } \\
\text { penilaian istri }\end{array}$ & Miskin & $\begin{array}{c}\text { Tidak } \\
\text { miskin }\end{array}$ & Total \\
\hline $\begin{array}{lrrr}\text { Peserta } \\
\text { Tidak sejahtera }\end{array}$ & 42,1 & 17,1 & 25,0 \\
Sejahtera & 57,9 & 82,9 & 75,0 \\
\hline Total & 100,0 & 100,0 & 100,0 \\
\hline Bukan Peserta & & & \\
Tidak sejahtera & 40,0 & 35,6 & 36,7 \\
Sejahtera & 60,0 & 64,4 & 63,3 \\
\hline Total & 100,0 & 100,0 & 100,0 \\
\hline $\begin{array}{lrrr}\text { Peserta + Bukan } \\
\text { Peserta }\end{array}$ & & \\
Tidak sejahtera & 41,2 & 26,7 & 30,8 \\
Sejahtera & 58,8 & 73,3 & 69,2 \\
\hline Total & 28,3 & 71,7 & 100,0 \\
\hline
\end{tabular}

\section{Variabel-variabel yang Memengaruhi Tingkat Kesejahteraan Keluarga}

Variabel yang memengaruhi tingkat kesejahteraan keluarga dianalisis dengan menggunakan regresi logistik. Uji ini hanya melibatkan 77 keluarga yang sejahtera atau tidak sejahtera berdasarkan hasil pengukuran kedua kriteria kesejahteraan yaitu kriteria BPS dan kriteria penilaian istri. Model regresi yang disusun memiliki persamaan koefisien determinasi (Nagelkerke $R^{2}$ ) sebesar 0,386. Koefisien ini menunjukkan bahwa 38,6 persen varian kesejahteraan keluarga dapat dijelaskan oleh perubahan variabel yang ada dalam model. Sisanya yaitu sebesar 61,4 persen varian kesejahteraan keluarga dipengaruhi oleh variabel lain yang tidak diteliti dalam penelitian ini.

Hasil analisis regresi logistik menunjukkan bahwa variabel yang berpengaruh signifikan terhadap kesejahteraan keluarga adalah aset keluarga. Keluarga dengan aset yang lebih banyak memiliki peluang untuk sejahtera lebih besar dibanding keluarga dengan aset sedikit. Pendidikan istri, optimalisasi pemanfaatan pekarangan dan keikutsertaan dalam program GPOP memiliki koefisien regresi positif terhadap tingkat kesejahteraan keluarga namun tidak berpengaruh signifikan. Sedangkan usia istri, pekerjaan istri, besar keluarga dan tempat tinggal memiliki koefisien regresi negatif terhadap tingkat kesejahteraan keluarga. Koefisien regresi untuk menganalisis pengaruh karakteristik keluarga, optimalisasi pemanfaatan pekarangan, dan keikutsertaan keluarga dalam program GPOP terhadap tingkat kesejahteraan keluarga disajikan pada Tabel 6 . 
Tabel 6 Hasil analisis regresi logistik faktorfaktor yang mempengaruhi tingkat kesejahteraan keluarga

\begin{tabular}{|c|c|c|c|}
\hline Variabel independen & $\mathrm{B}$ & $\operatorname{Exp}(\mathrm{B})$ & Sig. \\
\hline Konstanta & $-\overline{2}, 433$ & 0,088 & 0,449 \\
\hline Usia istri (tahun) & $-\overline{0}, 075$ & 0,927 & 0,188 \\
\hline $\begin{array}{l}\text { Pendidikan istri } \\
\text { (tahun) }\end{array}$ & 0,099 & 1,105 & 0,486 \\
\hline $\begin{array}{l}\text { Pekerjaan istri } \\
\text { ( } 0=\text { tidak bekerja, } \\
1=\text { tidak bekerja) }\end{array}$ & - & 0,828 & 0,829 \\
\hline $\begin{array}{l}\text { Besar keluarga } \\
\text { (orang) }\end{array}$ & $-\overline{0}, 205$ & 0,815 & 0,545 \\
\hline $\begin{array}{l}\text { Aset keluarga (jumlah } \\
\text { jenis aset) }\end{array}$ & 0,408 & 1,504 & $\underset{* \star}{0,004}$ \\
\hline $\begin{array}{l}\text { Tempat tinggal } \\
\text { (0=bukan komplek, } \\
1=\text { komplek) }\end{array}$ & $-\overline{1,255}$ & 0,285 & 0,170 \\
\hline $\begin{array}{l}\text { Optimalisasi } \\
\text { pemanfaatan } \\
\text { pekarangan (indeks) }\end{array}$ & 0,016 & 1,016 & 0,409 \\
\hline $\begin{array}{l}\text { Keikutsertaan } \\
\text { program GPOP } \\
(0=\text { Bukan peserta, } \\
1=\text { peserta) }\end{array}$ & 0,777 & 2,176 & 0,371 \\
\hline Chi-square & & 20,78 & \\
\hline$d f$ & & 8 & \\
\hline Sig. & & 0,386 & \\
\hline Nagelkerke $R^{2}$ & & $0,008^{* *}$ & \\
\hline
\end{tabular}

\section{PEMBAHASAN}

Kesejahteraan keluarga merupakan tujuan yang ingin dicapai setiap keluarga. Kesejahteraan dapat dilihat melalui dua pendekatan yaitu ekonomi dan penilaian subjektif. Kesejahteraan dapat diwujudkan apabila ekonomi keluarga dalam kondisi cukup sehingga kebutuhan anggota keluarga akan pangan, sandang, papan dan kebutuhan penting lainnya dapat terpenuhi (Siahaan, 2004). Namun menurut Martinez, Gertler, dan Rubio-Codina (2003) kesejahteraan keluarga tidak hanya ditentukan oleh aspek ekonomi saja, namun mencakup seluruh aspek kehidupan diantaranya kesehatan, pendidikan, dan sosial.

Faktor ekonomi merupakan faktor penting dalam menentukan kesejahteraan keluarga. Hasil penelitian menunjukkan bahwa aset keluarga berpengaruh secara signifikan terhadap kesejahteraan keluarga. Keluarga dengan jumlah aset lebih banyak berpotensi lebih besar untuk sejahtera dibandingkan keluarga dengan aset sedikit. Aset akan berperan sebagai alat pemuas kebutuhan. Oleh karena itu, keluarga yang memiliki aset lebih banyak cenderung lebih sejahtera jika dibandingkan dengan keluarga yang memiliki aset terbatas. Hal ini sejalan dengan hasil penelitian Muflikhati et al. (2010) dan Iskandar (2007) yang menyatakan bahwa aset berpengaruh signifikan terhadap kesejahteraan keluarga, semakin banyak aset yang dimiliki keluarga maka keluarga menjadi semakin sejahtera.

Pendidikan istri memiliki koefisien regresi positif terhadap tingkat kesejahteraan keluarga namun tidak berpengaruh signifikan. Keluarga dengan istri berpendidikan lebih tinggi berpotensi untuk lebih sejahtera dibandingkan keluarga dengan istri berpendidikan rendah. Istri dengan pendidikan lebih tinggi, dengan wawasan dan ketrampilan yang dimiliki mampu mengelola sumber daya keluarga yang ada secara lebih baik untuk memenuhi kebutuhan keluarga, sehingga kesejahteraan keluarga meningkat. Hal ini sejalan dengan pendapat Martinez, Gertler, \& Rubio-Codina (2003) yang menyatakan bahwa kesejahteraan keluarga tidak hanya ditentukan oleh aspek ekonomi saja, namun mencakup seluruh aspek kehidupan diantaranya kesehatan, pendidikan, dan sosial.

Bagi keluarga tidak miskin, istri yang bekerja tidak lagi ditujukan untuk menambah pendapatan keluarga, namun lebih kepada aktualisasi diri istri di tengah masyarakat. Banyaknya istri yang tidak bekerja pada keluarga yang tidak miskin sepertinya melahirkan ketidakpuasan karena tidak dapat mengaktualisasikan diri di masyarakat dan ini menyebabkan ketidaksejahteraan. Usia istri memiliki koefisien regresi negatif terhadap tingkat kesejahteraan keluarga. Keluarga dengan istri berusia muda berpotensi untuk lebih sejahtera dibanding keluarga dengan istri berusia tua. Hal ini disebabkan karena semakin tua, kondisi fisik dan kesehatan semakin menurun (Smith et al., 2002). Keadaan ini menyebabkan dampak psikologis bagi istri, yang menyebabkan istri merasa tidak sejahtera walaupun secara ekonomi sudah lebih dari cukup.

Pekarangan merupakan salah satu sumber daya keluarga, yang jika dikelola dengan baik dapat memberikan manfaat bagi keluarga, baik secara ekonomi maupun non ekonomi. Pekarangan dapat dimanfaatkan untuk menanam berbagai jenis tanaman, beternak atau memelihara ikan. Hasil penelitian menunjukkan optimalisasi pemanfaatan pekarangan memiliki koefisien regresi positif namun tidak signifikan terhadap kesejahteraan keluarga yang berarti 
bahwa keluarga yang memanfaatan pekarangan lebih optimal berpotensi lebih besar untuk sejahtera dibanding keluarga yang belum optimal memanfaatan pekarangan. Menurut Mitchell dan Hanstad (2004) pekarangan berkontribusi pada kesejahteraan ekonomi keluarga dalam berbagai cara.

Hasil penelitian menunjukkan, dengan ratarata luas pekarangan $52,63 \mathrm{~m}^{2}$ keluarga sudah memanfaatkannya seluas rata-rata $8,06 \mathrm{~m}^{2}$ untuk berkebun, beternak atau memelihara ikan. Pekarangan yang dimanfaatkan tersebut tidak luas namun hasil pekarangan dapat dikonsumsi sendiri oleh keluarga $(58,3 \%)$. Hal ini tentunya dapat mengurangi pengeluaran keluarga, sehingga pendapatan yang ada bisa dialokasikan untuk pemenuhan kebutuhan keluarga lainnya. Bahkan hasil pekarangan juga dapat dijual walau nilainya kecil $(14,2 \%)$, yang hasilnya dapat memberikan tambahan pendapatan keluarga.

Hasil ini sejalan dengan hasil penelitian Wickramasingle (1995) dan Torres (1988) yang menunjukkan bahwa pekarangan dapat menghasilkan makanan untuk konsumsi keluarga dan penyangga ekonomi keluarga pada saat terjadi fluktuasi harga. Selain itu hasil pekarangan dapat dijual untuk mendapatkan tambahan penghasilan (Niñez, 1985; Torquebiau, 1992). Penghasilan yang diperoleh dari penjualan buah, sayur dan ternak dari pekarangan memungkinkan keluarga untuk membeli makanan tambahan, menabung dan membiayai pendidikan anak-anak (Vasey, 1985; lannotti, Cunningham, \& Ruel, 2009). Hasil penelitian di Vietnam menunjukkan bahwa lebih dari 22 persen pendapatan keluarga diperoleh dari kegiatan di pekarangan (Trinh et al., 2003). Penelitian di Bangladesh menunjukkan bahwa pemanfaatan pekarangan dapat meningkatkan 8-10 persen pendapatan masyarakat (Midmore, Ninez, \& Venkataraman, 1996). Pekarangan selain bermanfaat secara ekonomis, juga sangat penting bagi perkembangan kesehatan fisik dan mental anggota keluarga (Freeman et al., 2012) juga dapat menciptakan lingkungan yang asri dan nyaman karena gaya hidup "hijau" yang dilakukan untuk mengatasi laju pemanasan global (Supriati, Yulia, \& Nurlela, 2008).

Keikutsertaan ibu dalam kegiatan GPOP memiliki koefisien regresi positif terhadap tingkat kesejahteraan keluarga namun tidak berpengaruh signifikan. Keluarga yang ikut program GPOP berpotensi untuk lebih sejahtera dibanding keluarga yang tidak ikut program. Hasil ini menunjukkan bahwa pencapaian tujuan dari pelaksanaan Program
GPOP sudah cukup baik. Program GPOP secara umum bertujuan untuk memotivasi/ menstimulasi masyarakat untuk mengoptimalkan pemanfaatan pekarangan sebagai sumber gizi, memperindah lingkungan dan menambah pendapatan keluarga. Keikutsertaan ibu dalam program GPOP yang juga merupakan anggota Kelompok Wanita Tani (KWT) dapat meningkatkan pengetahuan dan keterampilan ibuibu dalam mengelola pekarangan dan berbudidaya tanaman.

Hasil penelitian menunjukkan bahwa keluarga peserta GPOP dengan pekarangan yang lebih sempit dibanding keluarga bukan peserta, lebih banyak menanami pekarangan dengan jenis tanaman yang dapat dikonsumsi, seperti sayuran, buah dan tanaman obat. Selain itu dengan adanya program ini memungkinkan ibu-ibu para peserta saling berinteraksi. Menurut Keyes (2002), kontak sosial yang berkualitas dapat meningkatkan kesejahteraan. Pinquart dan Sorensen (2000), Diener \& Seligman (2002), dan Cooper, Okamura, \& Gurka (1992) juga menegaskan bahwa kegiatan sosial dengan kelompokkelompok berkorelasi kuat dengan kesejahteraan.

\section{SIMPULAN DAN SARAN}

Optimalisasi pemanfaatan pekarangan secara keseluruhan termasuk dalam kategori sedang. Optimalisasi pemanfaatan pekarangan keluarga peserta lebih tinggi dibanding bukan peserta, namun perbedaannya tidak signifikan. Sebagian besar keluarga sejahtera menurut pengukuran kedua kriteria, yaitu BPS dan penilaian istri. Keluarga peserta lebih sejahtera menurut pengukuran kedua kriteria dibanding keluarga bukan peserta. Jumlah aset keluarga berpengaruh secara signifikan terhadap tingkat kesejahteraan keluarga. Diperlukan upaya pemerintah untuk melakukan sosialisasi dan pelatihan pemanfaatan pekarangan dengan bercocok tanam atau memelihara ternak/ikan secara berkesinambungan, efektif, sehingga pemanfaatan pekarangan dapat dilakukan secara optimal.

\section{DAFTAR PUSTAKA}

Behnke, A., \& MacDermid. (2004). Family wellbeing. Purdue University.

Bubolz, M. M., \& Sontag, S. (1988). Integration in home economics and human ecology. Journal of Home Economics and Consumer Studies, 12(1), 1-14. 
Cooper, H., Okamura, L., \& Gurka, V. (1992). Social activity and subjective wellbeing. Personality and Individual Differences, 13(5), 573-583.

Diener, E. \& Seligman, M. E. P. ( 2002). Very happy people. Psychological Science, 13, 81-84.

Firebaugh, F. M. (1991). Families in transition: a global perspective. Journal of Home Economics, 83(3), 44-50.

Freeman, C. Dickinson, K. J. M., Porter, S., \& Van Heezik, Y. (2012). My garden is an expression of me: exploring householders' relationships with their gardens. Journal of Environmental Psychology, 32, 135-143.

Galhena, D. H., Freed, R., \& Maredia, K. M. (2013). Home gardens: a promising approach to enhance household food security and well-being. Agriculture \& Food Security, 2, 8.

lannotti, L., Cunningham, K., \& Ruel, M. (2009). Improving diet quality and micronutrient nutrition: Homestead food production in Bangladesh. International Food Policy Research Institute, Discussion Paper, 00928.

Iskandar, A. (2007). Analisis praktik manajemen sumberdaya keluarga dan dampaknya terhadap kesejahteraan keluarga di Kabupaten dan Kota Bogor. Jurnal Transdisiplin Sosiologi, Komunikasi, dan Ekologi Manusia, 1(3), 295-320.

Keyes, C. L. M. (2002). The exchange of emotional support with age and its relationship with emotional well-being by age. Journal of Gerontology: Psychological Sciences, 57(6), 518-525.

Martinez, S. W., Gertler P. J., \& Rubio-Codina, M. (2012). Investing cash transfer to raise long-term living standards. American Economic Journal: Applied Economics, 4(1), 1-32.

Midmore, J. M., Ninez, V., \& Venkataraman, R. (1996). Household gardening projects in asia: past experience and future directions. Technical Bulletin, 19, 16-17.

Milligan, S., Fabian, A., Coope, P. C., \& Errington. (2006). Family well-being indicators from the 1981-2001. New Zealand Censuses, Statistics New Zealand, Univ. of Auckland and Univ. of Otago.

Mitchell, R., \& Hanstad, T. (2004). Small homegarden plots and sustainable livelihoods for the poor. Rome, Italy: $L S P$ Working Paper, 11.

Muflikhati, I., Hartoyo, Sumarwan, U., Fahrudin, A., \& Puspitawati, H. (2010). Kondisi sosial ekonomi dan tingkat kesejahteraan keluarga: Kasus di wilayah pesisir Jawa Barat. Jurnal IImu Keluarga dan Konsumen, 3(1), 1-10.

Niñez, V. K. (1985). Working at half-potential: constructive analysis of homegarden programme in the Lima slums with suggestions for an alternative approach. Food Nutr Bull, 7(3), 6-13

Odebode, O. S. (2006). Assessment of home gardening as a potential source of household income in Akinyele Local Government Area of Oyo State. Nig J Horticulture Sci, 2, 47-55.

Pinquart, M. \& Sörensen, S. (2000). Influences of socio-economic status, social network, and competence on subjective well-being in later life: a meta-analysis. Psychology and Aging, 15, 187-224.

Puri, S., \& Nair, P. K. R. (2004). Agroforestry research for development in India: 25 years of experiences of a national program. Agrofor Sys, 61, 437-452.

Rowe, W. C. (2009). "Kitchen gardens" in Tajikistan: the economic and cultural importance of small-scale private property in a post-soviet society. Hum Ecol, 37(6), 691-703.

Smith, J., Borchelt, M., Maier, H., \& Jopp, D. (2002). Health and well-being in the young old and oldest old. Journal of Social Issues, 58(4), 715-732.

Supriati, Y., Yulia, Y., \& Nurlela, I. (2008). Taman Sayur +19 Desain Menarik. Jakarta, ID: Penebar Swadaya.

Terra, G. J. A. (1958). Farm systems in Southeast Asia. Neth J Agric Sci, 6, 157182.

Torres, E. B. (1988). Socioeconomic aspects of backyard gardening in the Philippines. Council for agriculture, Forestry and Natural Resources Research and Development. Report, 69.

Torquebiau, E. (1992). Are tropical agroforestry gardens sustainable?. Agric Ecosyst Environ, 41, 189-207. 
Trinh, L. N., Watson, J. W., Hue, N. N., De, N. N., Minh, N. V., Chu, P.,...Eyzaguirre, P. B. (2003). Agrobiodiversity conservation and development in Vietnamese home gardens. Journal of Agriculture, Ecosystems and Environment, 97, 317344.

Vasey, D. E. (1985). Household gardens and their niche in Port Moresby, Papua New Guinea. Food Nutr Bull, 7(3), 37-43.
Weston, R., Gray, M., Qu, L., \& Stanton, D. (2004). Long work hours and the wellbeing of fathers and their families. Australian Institute of Family Studies, Melbourne.

Wickramasingle, A. (1995). Home gardens: Habitations rescuing biodiversity. MPTS News, 4, 1-4. 